\title{
HRM Practices and Operational Performance at Jute Spinning Mills in Bangladesh
}

\author{
Mohammad Nasim Reza', Md. Faisal-E-Alam ${ }^{2 *}$ \\ ${ }^{1}$ Department of Management Studies, University of Rajshahi, Rajshahi-6205, Bangladesh \\ ${ }^{2}$ Department of Management Studies, Begum Rokeya University, Rangpur-5404, Bangladesh
}

*Correspondence E-mail: nasimreza981@yahoo.com; faisal14.ru@gmail.com

\begin{abstract}
This study is directed to concentrate on the practices of human resource management (HRM) in private enterprise as well as inspect the HRM practices affecting operational performance (non-financial). Survey questionnaire has been heading for collecting data from 120 staffs based on Random Sampling Technique working in three organizations to be specific Rahman Jute Spinners (Pvt.) Ltd., Jamuna Jute Industries Ltd. and North Bengal Golden Fiber \& Diversified Jute Mills which are working under Bangladesh Jute Spinners Association (BJSA). Correlation Test, ANOVA Test and Regression Coefficient Test were done to bring out the outcomes of the study. The results uncovered that, noteworthy and satisfactory relationship exists among HRM functions (namely practices of recruitment and selection, assessment of performance, compensation and reward, training and development) and performance of operations. This study gives insight in terms of ensuring sustainable operational performance by practice these HRM practices which will ultimately accelerate the productivity of employees as well as private jute mills in Bangladesh.
\end{abstract}

Keywords: Human Resource Management (HRM); Operational Performance; BJSA

JEL Classification: M5, M12, M50, 015

\section{Introduction}

The most crowded nation of the world is Bangladesh. Thus, labor or worker supply is enormous for both government and nongovernment firms. However, greatest part of the jute mills failed to ensure anticipated performance despite of having sufficient labor forces. HR are the utmost critical resource for the organizations. Small number of companies can completely suit the potentiality of HR. Before long, HRM practices impact employees' skills through the procurement and advancement of the company's human capital. The employees' understanding, skills and capabilities considered as main assets for the change of new process or existing process by which strategic advantage is achieved. Though, a large part of the past investigations on the connection between particular HRM practice and performance of organization. Additionally, it has been contended in increasing number of investigations for founding the HRM practices to improve performance of organization. Notwithstanding, not many investigations have analyzed the effect of HRM practices on performance measures (cost, quality, distribution and so forth) (Ahmad \& Schroeder, 2003). Accordingly, a gap in the examination exists in this study areas is substantial. On this premise, scholars studied in general HRM practices and review its impact on the performance of operation and finally to give administrative inferences and suggestions for better performance of three jute mills.

Armstrong (2006) stated that the hypotheses supporting the HRM practices is that individuals are the company's secret resource and 
performance of organization to a great extent relies upon them. If suitable HRM strategies are created and carried out adequately, HRM practices will have a significant effect on organizations' performance and success (Boohene \& Asuinura, 2011). Consistently, scientists have proposed various HRM practices that have the potential outcomes to escalate and support the financial and non-financial performance. The current study additionally presented vigorous comprehensions to the administration of jute factories regarding the meaning of HRM practices for prevalent and effective operational accomplishment in Bangladesh.

\section{Review of Literature:}

The practices of HRM are the system involved with appealing, inspiring, and holding staffs to guarantee the firms' existence (Schuler \& Jackson, 1987). Scholars observed a positive connection between actual practices of recruitment and selection and superior performance (Delaney \& Huselid, 1996; Harel \& Tzafrir, 1999), training and advancement (Bartel, 2000; Fey, Björkman \& Pavlovskaya, 2000); salary and benefits (Chiu, Luk \& Tang, 2002; Batt, 2002); evaluation of performance (Boselie, Paauwe \& Jansen, 2001, Björkman \& Xiucheng, 2002); coworkers relationships (Kuo, 2004). Experimental examinations have been expanded that analyzes the impact of certain practices of HRM on staffs' performance (Becker \& Huselid, 2006; Bowen \& Ostroff, 2004). In recent times, the emphasis of investigation on HRM has moved from the relationship of separate HRM function on performance of business to whole HRM framework and its impact on performance of firm (Khan, 2010).

Noe et al. (2007) said that, HRM practices and approaches that impact performance, mentalities and manners of staffs. They concentrated on a few significant practices which, sequentially, can affect performance of company indeed, for example, planning of human resources, procurement, selection, training, remuneration, managing performance and colleagues' relationships. These positive results in the organization should prompt more elevated levels of financial and non-financial performance (Collins, Ericksen \& Allen, 2005). In an investigation of Taiwanese and Cambodian managers, Chan (2005) presumed that planning of personnel, recruitment, pay and rewards, team and group work, training and employment security impacted monetary and non-monetary elements of firms' performance.

The monetary measures incorporate sales value, revenue, and market segment while nonmonetary measures incorporate superiority of product or service, output, competency, and attitudes and social measures, for example, loyalty, aim to stop, and pleasure (Dyer \& Reeves, 1995). Past examinations (Batt, 2002; Chuang \& Liao, 2010; MacDuffie, 1995; Gong et al., 2009; Chang, Gong \& Shum, 2011; Tiwari \& Saxena, 2012; Trehan \& Setia, 2014) have utilized different factors to study functional measures like work efficiency, production quality, organizational developments, and consumer satisfaction. In this review, various factors are utilized to quantify performance (non-monetary). In this way, companies have progressively perceived the prospects for their employees as a ground of competitive advantage (Pfeffer, 1994). Earlier examinations have approved the connection between HRM practices and performance of firms in USA and European countries (Boselie, Paauwe \& Jansen, 2001), Asian countries (Björkman \& Xiucheng, 2002) as well as Africa (Ghebregiorgis \& Karsten, 2007) which are also stated by Jalil, Shaikh and Alam (2014) and Khan (2010).

After reviewing a good quantity of literatures on the field, alternative hypotheses delineated and taken to attain the mentioned study objectives. Also, some important extractions from the investigation of literature are showed.

Hajer and Yusof (2013) have emphasized on human resources as a fact of ensuring and upgrading business performance of organizations because of poor HRM practices poses many problems to the organizations. Therefore, hiring and selecting best aspirants as employee is a challenge for a particular position. Huselid (1995) specified that in case of hiring new employees' recruitment system, it is beneficial to have an enormous pool of qualified and skilled competitors. It is proved that, the recruitment and selection practices and performance of organizations are significantly correlated (Gamage, 2014). A study showed that strong and effective recruitment and selection procedure is spotted with organizational performance (Syed \& Jamal, 2012). Thus, the first hypothesis is taken below.

H 1: The Recruitment and selection practices impacts on the performance of operations.

Appraising performance refers to the managers' task of judging employees' job-related behaviors to determine the productivity of employees' performance that focused on the improvement of 
employees' performance for the well-being of organizations (Walker, Damanpour \& Devece, 2011). Performance appraisal is a policy associated with human recourses as where it provides reports regarding employees' performances over a year generally (Akinbowale, Jinabhai \& Lourens, 2013). A systemized and conscious appraisal plan consists of prospective training and development necessities of employees. Performance appraisal sets up both direct and indirect impact on performance of administration (Collins \& Clark, 2003). Hence, the following second hypothesis claimed.

H2: There is direct association between appraisal of performance and operational performance.

Carraher, Gibson and Buckley (2006) gave his opinion that to maintain better performance in organization, it is a good way to reward employees according to their productive activities. Additionally, employees will do their activities willingly when they are confirmed that their performance will be praised with reward (Abdul Rashid et al., 2016; Cotter \& Zenner, 1994). However, recent days in organizations, employees' both job performance and satisfaction respectively depend on direct and indirect financial payment (Sopiah, 2013). Work performance can be increased when salaries could get attention (Qureshi \& Sajjad, 2015). This phase created to boost up performance and give better output (Boohene \& Asuinura, 2011). Therefore, the third one below considered as hypothesis.

H 3: The operational performance is enhanced due to the compensation and benefits practices.

Organizational dynamics includes enhancing trained manpower as priority. Train manpower involves process as a proven method for increasing productive capacity and communicating objectives from employee to employee (Galanou \& Priporas, 2009). Longenecker (2010) stated that, training program helped employees to be more productive and regulates better connectivity between organizations and employees practically. Additionally, according to Tsaur and Lin (2004), there is a significant link of training employee with improving the organizational activity. Moreover, upgrading employees' knowledge and performance, training plays as an instrument tool in the company (Castilla, 2005). Training works as motivation of employees who take part in various structured projects willingly that helps organizations to achieve goals (Gallos \& Bolman, 2021). Consequently, the fourth hypothesis is adopted below.

H 4: There is profound connection of training and development practices with performance of operations.

\section{Methodology}

A survey of questionnaire was done from 1st November to $31^{\text {st }}$ December in 2019. Eighty (150) questionnaires conveyed towards employees performing at different positions of the departments of these three jute mills for getting responses. 120 questionnaires were collected from 120 respondents occupying $80 \%$ of the total. The majority of the statements utilized as a part of this study were attracted from a profound investigation. Study items are taken from different examinations (Kundu \& Malhan, 2007; Lee \& Lee, 2007; Ghebregiorgis \& Karsten, 2007; Tzafir, 2005). This investigation explores four significant practices of HRM and its' effect on effective execution of operations. Each HR practices and operational performance is measured based on five items. However, the performance of nonfinancial (operations) variable is identified by quality, sales, productivity, performance in regard to rival industries and product development. For this study, Likert scale of five points utilized for evaluating responses. This study embraced the quantitative method using the SPSS version 20 as a part of the data analysis. The examination included diverse statistical approaches. Firstly, add up to single score of the practices of HRM and performances of operations. Then, Descriptive Statistics, Test of Cronbach's Alpha, Analysis of Demography and Correlation Coefficient Test are performed to evaluate the collected data. After that, ANOVA and Regression Coefficient Test are conducted to examine the hypotheses to reach the objectives. Finally, results are translated to discover knowledge and make implications about the affiliation of the practices of HRM with performance efficiency of three jute mills under BJSA.

\section{Conceptual Framework}

In the figure 1, conceptual framework for this study is displayed. Operational Performance is considered as dependent variable. While independent variables composed of RS practices, PA practices, CR practices, TD practices. These independent variables could impact operational 
performance thus supporting the dependent variable. Hence, the employees believe had strong positive effect. The practices of HRM contributed to the employees' perception that helped them to make satisfied workforce which ultimately ensure sound operational performance of the organization.

\section{Figure 1: Conceptual Framework}

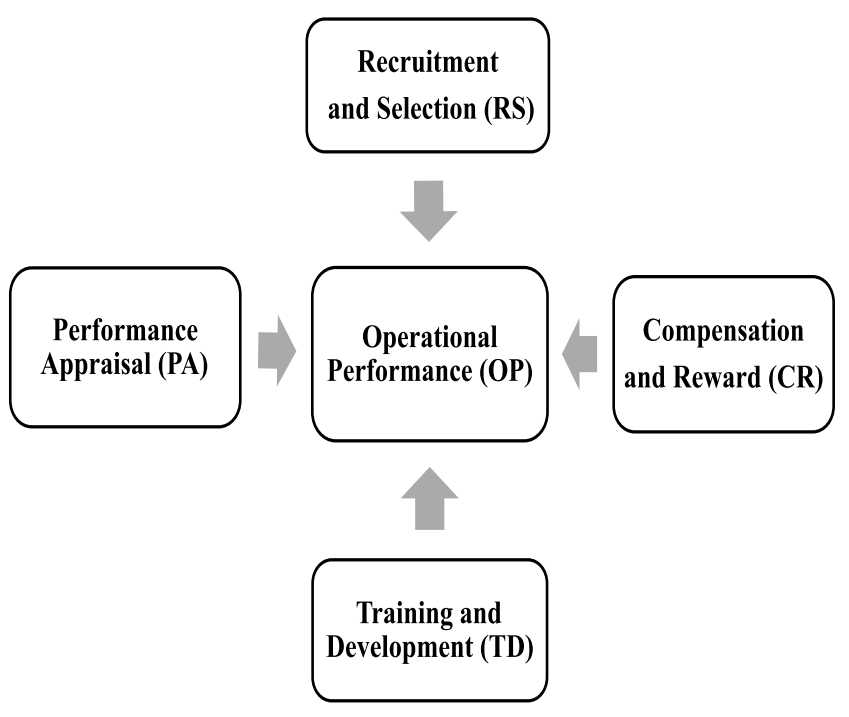

Source: Authors' Compilation

\section{Results and Discussion:}

\section{Descriptive Statistics}

The scores of mean and standard deviations mirror the congruity of employees' statement about the practices of HRM and non-financial performance of private jute mills (presented in table. 1). The values demonstrated general assertion of individual practices of HRM (to be specific RS, PA, CR, TD) and performance of operations. Since, the values of items' mean ranged from most noteworthy 3.040 to least 2.537. However, the standard deviation score of training and development showed distinctive impression of respondents about these HRM practices.

Table 1: Item Mean and Standard Deviation

\begin{tabular}{|l|c|c|c|}
\hline & N & Mean & Std. Deviation \\
\hline Recruitment and Selection (RS) & 120 & 2.8467 & 0.80408 \\
\hline Performance Appraisal (PA) & 120 & 2.7983 & 0.71220 \\
\hline Compensation and Reward (CR) & 120 & 3.0400 & 0.75664 \\
\hline Training and Development (TD) & 120 & 2.9200 & 1.00466 \\
\hline Operational Performance (OP) & 120 & 2.5367 & 0.84415 \\
\hline Valid N (listwise) & 120 & & \\
\hline
\end{tabular}

Source: Primary Data, 2019

\section{Reliability and Internal Consistency Test}

The estimation of Cronbach's Alpha that is 0.798 for the variables (Reliability Test appeared in the table. 2). Specifically, the scores of TD (0.880) and OP (0.875) are highest level indicating great reliability and internal consistency. However, the values of RS (0.717), PA (0.717) and CR (0.761) are found above adequate level (0.7). Employees' distinctive views about the practices of HRM, for example, recruitment and selection, performance evaluation may bring about the comparatively lower estimation of Cronbach's Alpha indicating lower reliability and internal consistency than other variables.

Table 2: Reliability Test

\begin{tabular}{|l|c|c|}
\hline \multicolumn{1}{|c|}{ Variables } & $\begin{array}{c}\text { Coefficient of } \\
\text { Cronbach's Alpha }\end{array}$ & $\begin{array}{c}\text { Cronbach's Alpha If } \\
\text { item deleted }\end{array}$ \\
\hline Recruitment and Selection (RS) & 0.703 & 0.717 \\
\hline Performance Appraisal (PA) & 0.694 & 0.717 \\
\hline Compensation and Reward (CR) & 0.727 & 0.761 \\
\hline Training and Development (TD) & 0.887 & 0.880 \\
\hline Operational Performance (OP) & 0.882 & 0.875 \\
\hline Overall Value for this study & 0.798 & \\
\hline
\end{tabular}

Source: Primary Data, 2019

\section{Demographic Analysis}

The results from analyzing demography showed that, $31.67 \%$ employees have studied up to HSC while $33.33 \%$ have honours degree. Among the respondents, the rest $31 \%$ discovered Master's degree and employees began with nearly high compensation taking into account their scholarly capability not their experience. In any case, $20 \%$ have less than 5 years working experience, though $30 \%$ have been working from $6-20$ years and the rest $50 \%$ have job experience from $21-40$ years. Shockingly, negative relationship existed between job experience and academic capability. The findings implied that most of the employees who have post-graduation quite the jute factories job for better advancement in career. In addition, $45 \%$ of the employees have age range from 24-35 years, while $30 \%$ from $36-50$ years and staying $25 \%$ have age of above 50 years. This result speaks to these three jutes mills that workforce is not overwhelmed by a specific age group. Moreover, $15 \%$ have female. It demonstrated workforce of jute mills is dominated by male employees.

\section{Correlation Analysis}

From correlation matrix table, the values found (appeared in the table. 3) showed the positive relationship of all the functions of HRM practices (RS, PA, CR, TD) with non-financial performance 
of jute mills. Overall, HRM practices are discovered strongly correlated to each other except the association between RS and CR that is statistically insignificant.

\section{Table 3: Correlation Matrix}

\begin{tabular}{|c|c|c|c|c|c|c|}
\hline & & RS & PA & CR & TD & OP \\
\hline \multirow{3}{*}{ RS } & Pearson Correlation & 1 & & & & \\
\hline & Sig. (2-tailed) & & & & & \\
\hline & $\mathrm{N}$ & 120 & & & & \\
\hline \multirow{3}{*}{ PA } & Pearson Correlation & $0.393^{* *}$ & 1 & & & \\
\hline & Sig. (2-tailed) & 0.000 & & & & \\
\hline & $N$ & 120 & 120 & & & \\
\hline \multirow{3}{*}{ CR } & Pearson Correlation & 0.129 & $0.371^{\star \star *}$ & 1 & & \\
\hline & Sig. (2-tailed) & 0.160 & 0.000 & & & \\
\hline & $\mathrm{N}$ & 120 & 120 & 120 & & \\
\hline \multirow{3}{*}{ TD } & Pearson Correlation & $0.376^{* *}$ & $0.403^{* *}$ & $0.538^{* *}$ & 1 & \\
\hline & Sig. (2-tailed) & 0.000 & 0.000 & 0.000 & & \\
\hline & $\mathrm{N}$ & 120 & 120 & 120 & 120 & \\
\hline \multirow{3}{*}{ OP } & Pearson Correlation & $0.247^{* *}$ & $0.504^{* * *}$ & $0.733^{* *}$ & $0.711^{* *}$ & 1 \\
\hline & Sig. (2-tailed) & 0.007 & 0.000 & 0.000 & 0.000 & \\
\hline & $\mathrm{N}$ & 120 & 120 & 120 & 120 & 120 \\
\hline
\end{tabular}

Source: Primary Data, 2019

\section{Hypotheses Testing}

For testing the hypotheses between the practices of HRM and operational performance, ANOVA Test is carried out in this study. Coefficient Test likewise conducted to assess the changing nature as these HRM practices found strong relationship with performance of operations of private jute mills. Moreover, mean scores of the item variables utilized in ANOVA and Coefficient Test.

The ANOVA test (shown in table. 4) demonstrates sum of squares for regression, residual and total. The calculated $F$ value is 7.670 with 0.007 significance level which is upper than table value. This test accepts the first hypothesis. Besides, calculated value of RS $(t=2.769, p<0.05)$ is also greater than table value (Coefficient Test displayed in table. 5). The Beta score of RS is 0.247 that indicates that 1 unit change in RS clarifies 0.247 unit increases in operational performance. In this way, the test confirms that recruitment and selection practices does affect the operational performance of jute mills. This positive connection implies that private jute mills ought to maintain the suitable candidate selection to gain effectiveness of performance and to reduce its' related expenses.

Table 4: ANOVA

\begin{tabular}{|l|l|c|c|c|c|c|}
\hline \multicolumn{2}{|c|}{ Model } & $\begin{array}{c}\text { Sum of } \\
\text { Squares }\end{array}$ & df & $\begin{array}{c}\text { Mean } \\
\text { Square }\end{array}$ & F & Sig. \\
\hline \multirow{3}{*}{1} & Regression & 5.175 & 1 & 5.175 & 7.670 & $0.007^{\text {a }}$ \\
\cline { 2 - 7 } & Residual & 79.623 & 118 & 0.675 & & \\
\cline { 2 - 7 } & Total & 84.799 & 119 & & & \\
\hline
\end{tabular}

Source: Primary Data, 2019

Table 5: Coefficient Test

\begin{tabular}{|c|c|c|c|c|c|c|c|c|}
\hline \multirow{2}{*}{\multicolumn{2}{|c|}{ Model }} & \multicolumn{2}{|c|}{$\begin{array}{l}\text { Unstandardized } \\
\text { Coefficients }\end{array}$} & \multirow{2}{*}{$\begin{array}{c}\begin{array}{c}\text { Standardized } \\
\text { Coefficients }\end{array} \\
\text { Beta }\end{array}$} & \multirow[t]{2}{*}{$t$} & \multirow{2}{*}{ Sig. } & \multicolumn{2}{|c|}{ 95\% Confidence Interval for B } \\
\hline & & $\mathrm{B}$ & Std. Error & & & & Lower Bound & Upper Bound \\
\hline \multirow{2}{*}{1} & (Constant) & 1.798 & 0.277 & & 6.494 & 0.000 & 1.250 & 2.347 \\
\hline & RS & 0.259 & 0.094 & 0.247 & 2.769 & 0.007 & 0.074 & 0.445 \\
\hline
\end{tabular}

Source: Primary Data, 2019

For the second hypothesis, the ANOVA Test (presented in table. 6) given a positive value of 40.209 at 0.000 significance. The calculated $t$ value of PA is 6.341 where $p$ value $(p<0.05)$ is more than table value (shown in table. 7 ). This result shows that strong performance appraisal practices completely influence the operational performance of jute mills. Moreover, Beta score of $\mathrm{PA}$ is 0.504 which directs that 1-unit change in PA describes 0.504 unit increases in Operational Performance. This finding prove that employees of jute mills will have the ability to provide more effort to operational performance if the performance appraisal framework is suitable.

Table 6: ANOVA

\begin{tabular}{|c|l|c|c|c|c|c|}
\hline \multicolumn{2}{|c|}{ Model } & $\begin{array}{c}\text { Sum of } \\
\text { Squares }\end{array}$ & df & $\begin{array}{c}\text { Mean } \\
\text { Square }\end{array}$ & F & Sig. \\
\hline \multirow{3}{*}{1} & Regression & 21.552 & 1 & 21.552 & 40.209 & $0.000^{\mathrm{a}}$ \\
\cline { 2 - 7 } & Residual & 63.247 & 118 & 0.536 & & \\
\cline { 2 - 7 } & Total & 84.799 & 119 & & & \\
\hline
\end{tabular}

a. Predictors: (Constant), PA

b. Dependent Variable: OP

Source: Primary Data, 2019 
Table 7: Coefficient Test

\begin{tabular}{|c|c|c|c|c|c|c|c|}
\hline \multirow{2}{*}{ Model } & \multicolumn{2}{|c|}{$\begin{array}{l}\text { Unstandardized } \\
\text { Coefficients }\end{array}$} & \multirow{2}{*}{$\begin{array}{c}\begin{array}{c}\text { Standardized } \\
\text { Coefficients }\end{array} \\
\text { Beta }\end{array}$} & \multirow[t]{2}{*}{$t$} & \multirow[t]{2}{*}{ Sig. } & \multicolumn{2}{|c|}{$95 \%$ Confidence Interval for B } \\
\hline & $B$ & Std. Error & & & & Lower Bound & Upper Bound \\
\hline (Constant) & 0.865 & 0.272 & & 3.178 & 0.002 & 0.326 & 1.403 \\
\hline 1 PA & 0.598 & 0.094 & 0.504 & 6.341 & 0.000 & 0.411 & 0.784 \\
\hline
\end{tabular}

Source: Primary Data, 2019

The calculated value of $F$ in testing third hypothesis is 136.917 with the significant level of 0.000 (demonstrated in table. 8). Likewise, the calculate $t$ value is 11.701 and the $p$-value of the connection between compensation and reward and operational performance is 0.000 (given in table. 9). This value is lesser than predetermined significant level of 0.05 . The Beta score is 0.733 for $C R$ that states that 1 -unit change in CR refers to 0.733 unit rises in operational performance. Along with these lines, it affirms that competitive compensation and reward practices significantly impact the operational performance of jute mills. It also illustrates that jute mills should ensure agreeable compensation and reward for every employee with the purpose of setting and accomplishing the organizational objectives successfully.

Table 8: ANOVA

\begin{tabular}{|l|l|c|c|c|c|c|}
\hline \multirow{2}{*}{1 Model } & $\begin{array}{c}\text { Sum of } \\
\text { Squares }\end{array}$ & df & $\begin{array}{c}\text { Mean } \\
\text { Square }\end{array}$ & F & Sig. \\
\hline \multirow{3}{*}{1} & $\begin{array}{l}\text { Regression } \\
\text { Residual } \\
\text { Total }\end{array}$ & 45.546 & 1 & 45.546 & 136.917 & $0.000^{\text {a }}$ \\
\cline { 2 - 6 } & 39.253 & 118 & 0.333 & & \\
\cline { 2 - 6 } & 84.799 & 119 & & & \\
\hline
\end{tabular}

Table 9: Coefficient Test

\begin{tabular}{|c|c|c|c|c|c|c|c|c|}
\hline & \multirow{2}{*}{ Model } & \multicolumn{2}{|c|}{$\begin{array}{l}\text { Unstandardized } \\
\text { Coefficients }\end{array}$} & \multirow{2}{*}{$\begin{array}{c}\begin{array}{c}\text { Standardized } \\
\text { Coefficients }\end{array} \\
\text { Beta }\end{array}$} & \multirow{2}{*}{$t$} & \multirow{2}{*}{ Sig. } & \multicolumn{2}{|c|}{$95 \%$ Confidence Interval for B } \\
\hline & & $\mathrm{B}$ & Std. Error & & & & Lower Bound & Upper Bound \\
\hline \multirow{2}{*}{1} & (Constant) & 0.051 & 0.219 & & 0.233 & 0.816 & -0.382 & 0.484 \\
\hline & CR & 0.818 & 0.070 & 0.733 & 11.701 & 0.000 & 0.679 & 0.956 \\
\hline \multicolumn{9}{|c|}{ a. Dependent Variable: OP } \\
\hline
\end{tabular}

Source: Primary Data, 2019

In testing fourth hypothesis, the $F$ value gives score of 120.881 at significant level of 0.000 (demonstrated in table. 10) and the p-value of the link between employee training and development and operational performance is lower than the significance level of 0.05 (presented in table. 11). Like this, the hypothesis test revealed that effective training and development practices have noteworthy association with operational performance of jute mills. This relationship implies that the private jute mills ought to escalate this relationship to increase the operational performance. Hence, this finding shows that effective training and development program is needed which requires participation of all employees for the accomplishment of predetermined objective.

Table 10: ANOVA

\begin{tabular}{|l|l|c|c|c|c|c|}
\hline \multicolumn{2}{|c|}{ Model } & $\begin{array}{c}\text { Sum of } \\
\text { Squares }\end{array}$ & df & $\begin{array}{c}\text { Mean } \\
\text { Square }\end{array}$ & F & Sig. \\
\hline \multirow{2}{*}{1} & Regression & 42.911 & 1 & 42.911 & 120.881 & $0.000^{\mathrm{a}}$ \\
\cline { 2 - 7 } & Residual & 41.888 & 118 & 0.355 & & \\
\cline { 2 - 7 } & 84.799 & 119 & & & \\
\hline
\end{tabular}

Source: Primary Data, 2019 
Table 11: Coefficient Test

\begin{tabular}{|c|c|c|c|c|c|c|c|c|}
\hline & \multirow[t]{2}{*}{ Model } & \multicolumn{2}{|c|}{$\begin{array}{l}\text { Unstandardized } \\
\text { Coefficients }\end{array}$} & \multirow{2}{*}{$\begin{array}{c}\begin{array}{c}\text { Standardized } \\
\text { Coefficients }\end{array} \\
\text { Beta }\end{array}$} & \multirow[t]{2}{*}{$t$} & \multirow[t]{2}{*}{ Sig. } & \multicolumn{2}{|c|}{$95 \%$ Confidence Interval for B } \\
\hline & & $B$ & Std. Error & & & & Lower Bound & Upper Bound \\
\hline \multirow{2}{*}{1} & (Constant) & 0.791 & 0.168 & & 4.716 & 0.000 & 0.459 & 1.124 \\
\hline & TD & 0.598 & 0.054 & 0.711 & 10.995 & 0.000 & 0.490 & 0.705 \\
\hline
\end{tabular}

Source: Primary Data, 2019

This study clearly revealed the positive association of the practices of (RS, PA, CR, TD) with operational performance on the basis of Correlation Test, ANOVA Test and Regression Coefficient Analysis. The study supervised by Singh (2004) showed an effective relationship between practices of HRM and performance of staffs (Qureshi, Ramay \& Marwat, 2006). The effect of hiring and selection practices on the operational activities reflected significant as it is supported by other studies (Harel \& Tzafrir,1996; Delaney \& Huselid, 1996). Furthermore, PA has satisfactory result which identified by other researchers (Boselie, Paauwe \& Jansen, 2001; Björkman \& Xiucheng, 2002). On the other hand, compensation and reward practices found remarkable for the non-financial performance of jute factories. Also, the outcomes were similar from the findings of Phillips (2009) that the impact of training on performance of teachers in education institutions.

\section{Recommendations}

As indicated by the findings, feasible practices of HRM viewed as a foundation of private jute mills' performance of operations. Therefore, it is suggested that private jute mills' administration needs to confirm the HRM processes as well as strategies which are successfully prepared and carried out to perform consistently. Also, the organizational HRM practices have to be communicated to every employee clearly as they make sure widespread application of the strategies. Nevertheless, administration likewise should set up particular and effective standard policies for every HRM function that influence operational efficiency.

At first, unbiased recruitment and selection procedure need to develop to hire skilled staffs as successful recruitment and selection procedures will make sure constructive performance and also repay for the company by reducing training and development costs of employees. Secondly, the application of performance evaluation truly to inspire the best using of employees' endeavors. Thirdly, attractive compensation and reward framework should be considered specific activity as well as employees' development. Moreover, administration must make sure a reasonable offset inside monetary and non-monetary benefits to enhance performance. Fourthly, administration of private jute mills should assure need based training and development courses to enhance present staff performance at work as positive connection found between training and development programs with performance of operations in this research.

Indeed, administration of each private jute mill is liable for the operational performance. They adopt the standard guidelines and measures in authoritative limit though they face limitations in setting HRM policies. If BJSA cannot control any guideline, the detailed policies may be suggested regarding performance efficiency for authorization. Besides, effective decisions and performance strategies should be made by government to make sure acceptable operational performance of private jute mills of Bangladesh.

\section{Conclusion:}

Lastly, the study outcomes are required to offer insights to administration of private jute mills about the significance of HRM functions for higher and possible operational activities. Nonetheless, current study could be more effective if some other mills considered which are regulated under BJSA. This examination has the typical restrictions in the relevant areas. First of all, the study concentrated on three factories in Rajshahi. In addition, just 120 employees did not represent the greater part of the industries. Some of the respondents were felt hesitation to remark on questionnaire survey regarding particular organization because the procedures rely on employers. Therefore, this study did not assemble solid and dependable proof to generate knowledge. Also, future study 
can likewise be conducted in different areas, comprising of an evaluation between both government and private jute factories and proposition can establish to incorporate different elements of the performance efficiency.

\section{Acknowledgements:}

The authors are thankful to the administration of three jute mills in Rajshahi as well as Bangladesh Jute Spinners Association (BJSA) for completing the work.

\section{Conflicts of Interest:}

The authors proclaim that the study was accomplished without interruptions of any other business organizations or associations so that no potential conflict of interest existed in this review of research.

\section{References}

Abdul Rashid, M. A., Othman, M. N., Othman, M. Z., \& Fatini, N. (2016). The Influence of the Types of Compensation (Financial and Non-Financial) on Job Performance Among Employees at the Employees' Provident Fund (EPF) in Kuala Terengganu, Terengganu, Malaysia. Global Journal of Business and Social Science Review, 4(1), 24-30.

Ahmad, S., \& Schroeder, R. G. (2003). The impact of human resource management practices on operational performance: recognizing country and industry differences. Journal of Operations Management, 21(1), 19-43.

Akinbowale, M. A., Jinabhai, D. C., \& Lourens, M. E. (2013). The impact of performance appraisal policy on employee performance-A case study of Guaranty Trust Bank in Nigeria. Mediterranean Journal of Social Sciences, 4(14), 677.

Armstrong, M. (2006). A Handbook of Human Resource Management Practice. Kogan Page Publishers.

Bartel, A. P. (2000). Human resource management and performance in the service sector: the case of bank branches. National Bureau of Economic Research (NBER), Working Paper. 7467.

Batt, R. (2002). Managing customer services: Human resource practices, quit rates, and sales growth. Academy of Management Journal, 45(3), 587-597.

Becker, B. E., \& Huselid, M. A. (2006). Strategic human resources management: where do we go from here?. Journal of Management, 32(6), 898925.

Björkman, I., \& Xiucheng, F. (2002). Human resource management and the performance of Western firms in China. International Journal of Human Resource Management, 13(6), 853-864.

Gallos, J. V., \& Bolman, L. G. (2021). Reframing Academic Leadership. John wiley \& sons.

Boohene, R., \& Asuinura, E. L. (2011). The effect of human resource management practices on corporate performance: A study of graphic communications group limited. International Business Research, 4(1), 266-272.

Boselie, P., Paauwe, J., \& Jansen, P. (2001). Human resource management and performance: lessons from the Netherlands. International Journal of Human Resource Management, 12(7), 1107-1125.

Bowen, D. E., \& Ostroff, C. (2004). Understanding HRM-firm performance linkages: The role of the "strength" of the HRM system. Academy of Management Review, 29(2), 203-221.

Carraher, S. M., Gibson, J. W., \& Buckley, M. R. (2006). Compensation satisfaction in the Baltics and the USA. Baltic Journal of Management.

Castilla, E. J. (2005). Social networks and employee performance in a call center. American Journal of Sociology, 110(5), 1243-1283.

Chan, S. (2005). Relationship between HRM practices and the perception of organizational performance, roles of management style, social capital, and culture: comparison between manufacturing firms in Cambodia and Taiwan. National Cheng Kung University, 1-181.

Chang, S., Gong, Y., \& Shum, C. (2011). Promoting innovation in hospitality companies through human resource management practices. International Journal of Hospitality Management, 30(4), 812-818.

Chiu, R. K., Luk, V. W. M., \& Tang, T. L. P. (2002). Retaining and motivating employees: Compensation preferences in Hong Kong and China. Personnel Review, 31(4), 402-431.

Chuang, C. H., \& Liao, H. U. I. (2010). Strategic human resource management in service context: Taking care of business by taking care of employees and customers. Personnel Psychology, 63(1), 153-196.

Collins, C. J., Ericksen, J., \& Allen, M. (2005). 
Employee outcomes: human resource management practices and firm performance in small businesses.

Collins, C. J., \& Clark, K. D. (2003). Strategic human resource practices, top management team social networks, and firm performance: The role of human resource practices in creating organizational competitive advantage. Academy of Management Journal, 46(6), 740-751.

Cotter, J. F., \& Zenner, M. (1994). How managerial wealth affects the tender offer process. Journal of Financial Economics, 35(1), 63-97.

Delaney, J. T., \& Huselid, M. A. (1996). The impact of human resource management practices on perceptions of organizational performance. Academy of Management Journal, 39(4), 949969.

Dyer, L., \& Reeves, T. (1995). Human resource strategies and firm performance: what do we know and where do we need to go?. International Journal of Human Resource Management, 6(3), 656-670.

Fey, C. F., Björkman, I., \& Pavlovskaya, A. (2000). The effect of human resource management practices on firm performance in Russia. International Journal of Human Resource Management, 11(1), 1-18.

Galanou, E., \& Priporas, C. V. (2009). A model for evaluating the effectiveness of middle managers' training courses: evidence from a major banking organization in Greece. International Journal of Training and Development, 13(4), 221-246.

Gamage, A. S. (2014). Recruitment and selection practices in manufacturing SMEs in Japan: An analysis of the link with business performance. Ruhuna Journal of Management and Finance, 1(1), 37-52.

Ghebregiorgis, F., \& Karsten, L. (2007). Employee reactions to human resource management and performance in a developing country: Evidence from Eritrea. Personnel Review, 36(5), 722-738.

Gong, Y., Law, K. S., Chang, S., \& Xin, K. R. (2009). Human resources management and firm performance: The differential role of managerial affective and continuance commitment. Journal of Applied Psychology, 94(1), 263.

Hajer, M. A., \& Yusof, Z. M. (2013). Building Selfconfidence and Self-efficacy among Employees in the Iraqis Small and Medium Enterprises (SMES) Based on Business Process Reengineering
(BPR) Tools: A Proposal New BPR Model. Management, 3(1), 45-49.

Harel, G. H., \& Tzafrir, S. S. (1999). The effect of human resource management practices on the perceptions of organizational and market performance of the firm. Human Resource Management: Published in Cooperation with the School of Business Administration, The University of Michigan and in alliance with the Society of Human Resources Management, 38(3), 185-199.

Huselid, M. A. (1995). The impact of human resource management practices on turnover, productivity, and corporate financial performance. Academy of Management Journal, 38(3), 635672.

Jalil, M. A., Shaikh, M. A. H., \& Alam, M. J. (2014). Human resource management practices and operational performance: an empirical study on kushtia sugar mills Itd. Human Resource Management, 5(1).

Khan, M. A. (2010). Effects of human resource management practices on organizational performance-an empirical study of oil and gas industry in Pakistan. European Journal of Economics, Finance and Administrative Sciences, 24(157-174), 6.

Kundu, S. C., \& Malhan, D. (2007). Human resource management practices in insurance companies operating in India: A Study. In Proceedings of the $13^{\text {th }}$ Asia Pacific Management Conference, Melbourne, Australia (pp. 472-488).

Kuo, H. P. (2004). The relationship between Human Resource Management practices, employee commitment, and operational performance in the healthcare institutions. National Cheng Kung University.

Lee, F. H., \& Lee, F. Z. (2007). The relationships between HRM practices, Leadership style, competitive strategy and business performance in Taiwanese steel industry. In Proceedings of the $13^{\text {th }}$ Asia Pacific Management Conference, Melbourne, Australia (Vol. 2007, pp. 953-971).

Longenecker, C. O. (2010). Barriers to managerial learning: lessons for rapidly changing organizations. Development and Learning in Organizations: An International Journal.

MacDuffie, J. P. (1995). Human resource bundles and manufacturing performance: Organizational logic and flexible production systems in the world auto industry. ilr Review, 48(2), 197-221.

Noe, R., Hollenbeck, J. R., Gerhart, B., \& Wright, 
P. M. (2007). Fundamentals of Human Resource Management (2nd ed.). McGraw Hill, New York City.

Pfeffer, J. (1994). Competitive advantage through people: Unleashing the power of the work force (No. 04; e-book.).

Phillips, E. (2009). The effect of tenure on teacher performance in secondary education.

Qureshi, M. O., \& Sajjad, S. R. (2015). An Empirical Analysis of the Impact of Compensation on Job Performance and Work-Family Conflict in the Kingdom of Saudi Arabia a Correlation Model. European Scientific Journal February 2015 Edition, 11(4), 170-187.

Qureshi, M. T., Ramay, I. M., \& Marwat, Z. A. (2006). Impact of human resource management practices on organizational performance in Pakistan. Muhammad Ali Jinnah University Islamabad, 1(3), 45-67.

Schuler, R. S., \& Jackson, S. E. (1987). Linking competitive strategies with human resource management practices. Academy of Management Perspectives, 1(3), 207-219.

Singh, K. (2004). Impact of HR practices on perceived firm performance in India. Asia Pacific Journal of Human Resources, 42(3), 301-317.

Sopiah, S. (2013). The effect of compensation toward job satisfaction and job performance of outsourcing employees of Syariah banks in Malang, Indonesia. International Journal of Learning \& Development, 3(2), 77-91.

Syed, Z. J. W., \& Jamal, W. (2012). Universalistic perspective of HRM and organizational performance: meta-analytical study. International Bulletin of Business Administration, 13(4), 45-57.

Tsaur, S. H., \& Lin, Y. C. (2004). Promoting service quality in tourist hotels: the role of HRM practices and service behavior. Tourism Management, 25(4), 471-481.

Tiwari, P., \& Saxena, K. (2012). Human resource management practices: A comprehensive review. Pakistan Business Review, 9(2), 669-705.

Trehan, S., \& Setia, K. (2014). Human resource management practices and organizational performance: an Indian perspective. Global Journal of Finance and Management, 6(8), 789-796.

Tzafrir, S. S. (2005). The relationship between trust, HRM practices and firm performance. The International Journal of Human Resource Management, 16(9), 1600-1622.

Walker, R. M., Damanpour, F., \& Devece, C. A. (2011). Management innovation and organizational performance: The mediating effect of performance management. Journal of Public Administration Research and Theory, 21(2), 367-386. 